\title{
Differential diagnosis of congenital megaprepuce: therapeutic and prognostic relevance
}

\author{
J. Arredondo Montero, Y. González Ruiz, J.V. Redondo Sedano, S. Hernández Martín, L. Ayuso González, C. Bardají Pascual
}

Navarra Hospital Complex. Pamplona, Navarra.

\begin{abstract}
Congenital megaprepuce is a urological pathology typical of childhood. It can be easily mistaken for other clinical entities such as physiological phimosis or buried penis. Owing to the risk of associated complications - primarily infectious and obstructive complications, with upper urinary tract involvement -, achieving an accurate diagnosis proves particularly significant for early treatment initiation. We present three cases of congenital megaprepuce diagnosed and operated on at our department from January 2019 to May 2020. Diagnosis, therapy, and clinical progression are described.
\end{abstract}

Key Words: Megaprepuce; Congenital; Phimosis; Penis; Buried; Ballooning, Preputioplasty; Circumcision; Technique.

\section{DIAGNÓSTICO DIFERENCIAL DEL MEGAPREPUCIO CONGÉNITO: RELEVANCIA TERAPÉUTICA Y PRONÓSTICA}

\section{RESUMEN}

El megaprepucio congénito es una patología urológica propia de la infancia que puede ser fácilmente confundida con otras entidades clínicas como la fimosis fisiológica o el pene enterrado. Debido al riesgo de complicaciones asociadas, principalmente de carácter infeccioso u obstructivo con afectación del tracto urinario superior, es importante incidir en su correcto diagnóstico de cara a ofertar un tratamiento precoz. Presentamos tres casos de megaprepucio congénito, diagnosticados e intervenidos en nuestro servicio durante el periodo comprendido entre enero de 2019 y mayo de 2020, describiéndose el diagnóstico, la terapéutica empleada y la evolución clínica.

Palabras Clave: Megaprepucio congénito; Fimosis; Pene enterrado; Balonización, Prepucioplastia; Circuncisión.

DOI: $10.54847 /$ cp. 2022.01 .20

Corresponding author: Dr. Javier Arredondo Montero.

E-mail address: Javier.montero.arredondo@gmail.com

Date of submission: September 2020 Date of acceptance: February 2021
Congenital megaprepuce is a rare pathology. It is characterized by redundant preputial mucosa along with a partial defect of the ventral preputial skin, which is thickened. This causes the penis to be fully covered, usually with no additional penile disorders ${ }^{(1)}$. Preputial ballooning as a result of urinary retention is the most common clinical presentation. Diagnosis is clinical(2), with no additional tests being required unless other genital and urological pathologies are suspected.

Understanding congenital megaprepuce is important for various reasons - it is often associated with urinary tract infections, it has significant esthetic implications, and it requires a surgical management different from that of conventional phimosis.

Differential diagnosis of congenital megaprepuce includes two clinical entities mainly -physiological phimosis and buried penis.

Physiological phimosis, which is caused by an incomplete separation of the epithelial layers of the glans and the prepuce, and also as a result of the conic shape of the glans, is a frequent entity present in up to $96 \%$ of newborns. In most cases, it spontaneously disappears before the child turns 4. Surgical management is typically conservative, with topical corticosteroid therapy and hygienic measures. Surgery -either preputioplasty or circumcision-is limited to complex cases, such as repeated balanoposthitis, urinary tract infection, or cases refractory to medical treatment.

Buried penis belongs to the spectrum of penoscrotal fusion abnormalities. In buried penis, the penis is anchored to the deep fascia through abnormal dartos attachments, and also as a result of a scrotum-skin attachment extending distally, which visually leads to the erroneous impression of micropenis. Multiple proposals have been made for buried penis surgical repair, such as Maizels' technique. However, there is no consensus as to whether congenital megaprepuce should be regarded as an independent entity from buried penis requiring a specific surgical management. 


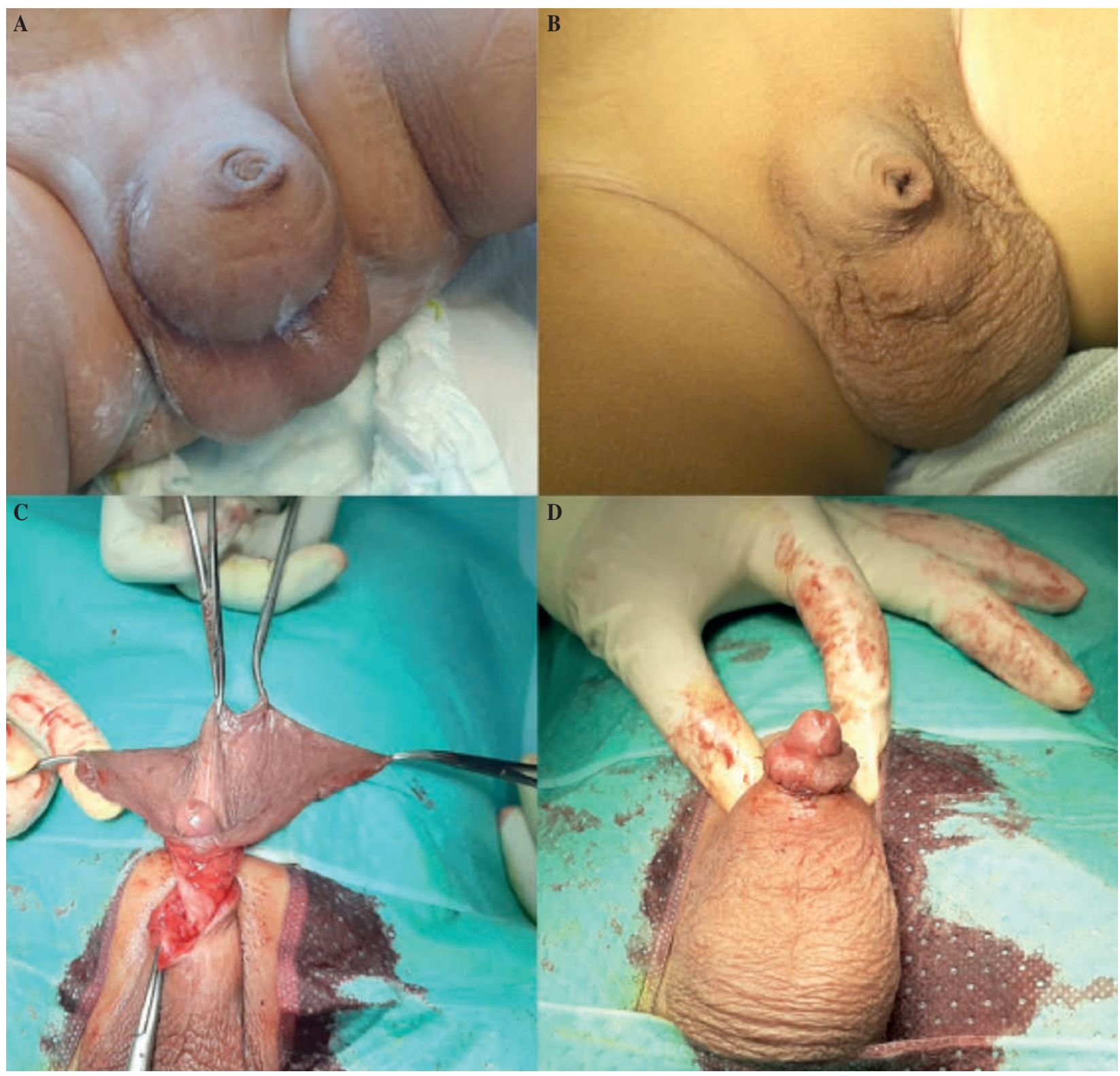

Figure 1. Clinical case 1. A) Ballooning as a result of urinary accumulation at the balanopreputial space. B) Baseline status prior to surgery. C) Exposure of the redundant mucosa characteristic of congenital megaprepuce. D. Immediate postoperative result.

3 cases of congenital megaprepuce diagnosed and surgically treated at our healthcare facility are presented. In the first two cases, surgery was carried out before the patient turned 1 , in order to repair ballooning and prevent complications. In the third case, a single-stage repair surgery was performed at the age of 17 months.

In all patients, baseline assessment revealed preputial ballooning as a result of urinary retention caused by the preputial orifice being too narrow. Two patients had had urinary tract infections prior to our assessment.

The first patient had a medical history of pyelonephritis. Diagnosis of scarring pinhole phimosis with significant preputial ballooning was established. Since phimosis was refractory to medical treatment -topical corticosteroids-, regulated circumcision was decided upon. During surgery, significantly redundant preputial mucosa was noted. It was resected and reconstructed by applying an absorbable suture on the mucocutaneous tissue, as established by our healthcare facility's protocol (Fig. 1). In the immediate postoperative period, the penis became increasingly buried within the scrotal region. This was managed with corticosteroids while monitoring progression, which was favorable on the following postoperative days. 


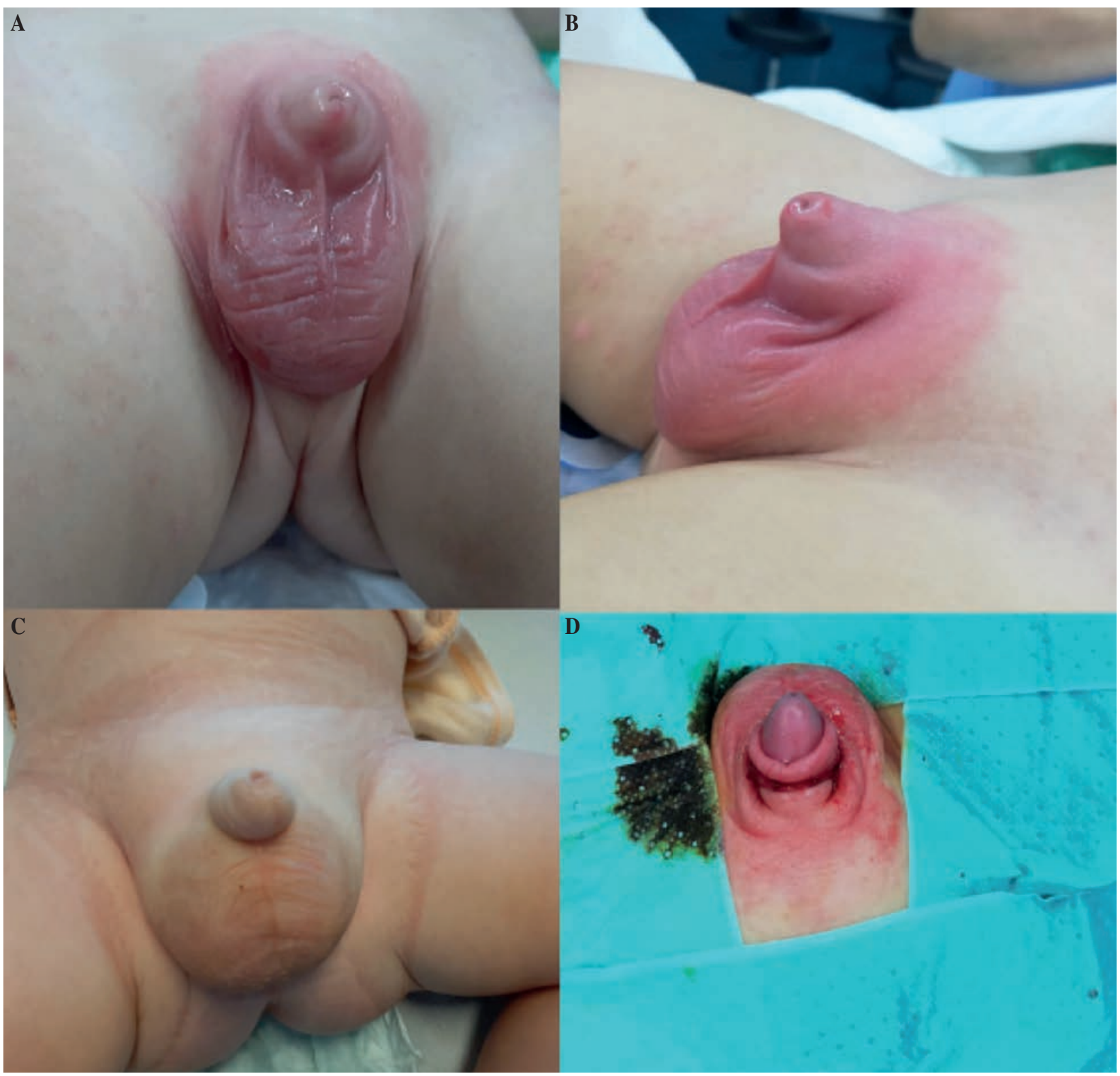

Figure 2. Clinical case 2. A) Baseline status, with an evident perigenital erythema. B) Lateral view. C) Ballooning as a result of urinary accumulation at the balanopreputial space. D) Immediate postoperative result.

The second patient had a medical history of repeated urinary infections. Physical exploration demonstrated a narrow prepuce with ballooning and significant perigenital erythema, most likely caused by chemical irritation as a result of urinary leakage. Diagnosis of congenital megaprepuce was established, and preputioplasty according to Duhamel's technique was indicated as an intermediate step before definitive repair (Fig. 2). Postoperative progression was favorable.

The third patient had a medical history of isolated urinary infection. Physical exploration demonstrated a narrow prepuce with ballooning. Diagnosis of congenital mega- prepuce was established, and surgical repair according to the "anatomical approach" technique was indicated (Fig. 3 ). During surgery, ulcerative lesions diffusely distributed throughout the glans were observed. The patient had a favorable progression in the immediate postoperative period.

External follow-up consultations were scheduled in all three cases one month and six months following surgery. No postoperative complications were noted. All patients experienced significant functional improvement, with urination becoming increasingly normal and preputial ballooning becoming increasingly repaired. The esthetics 


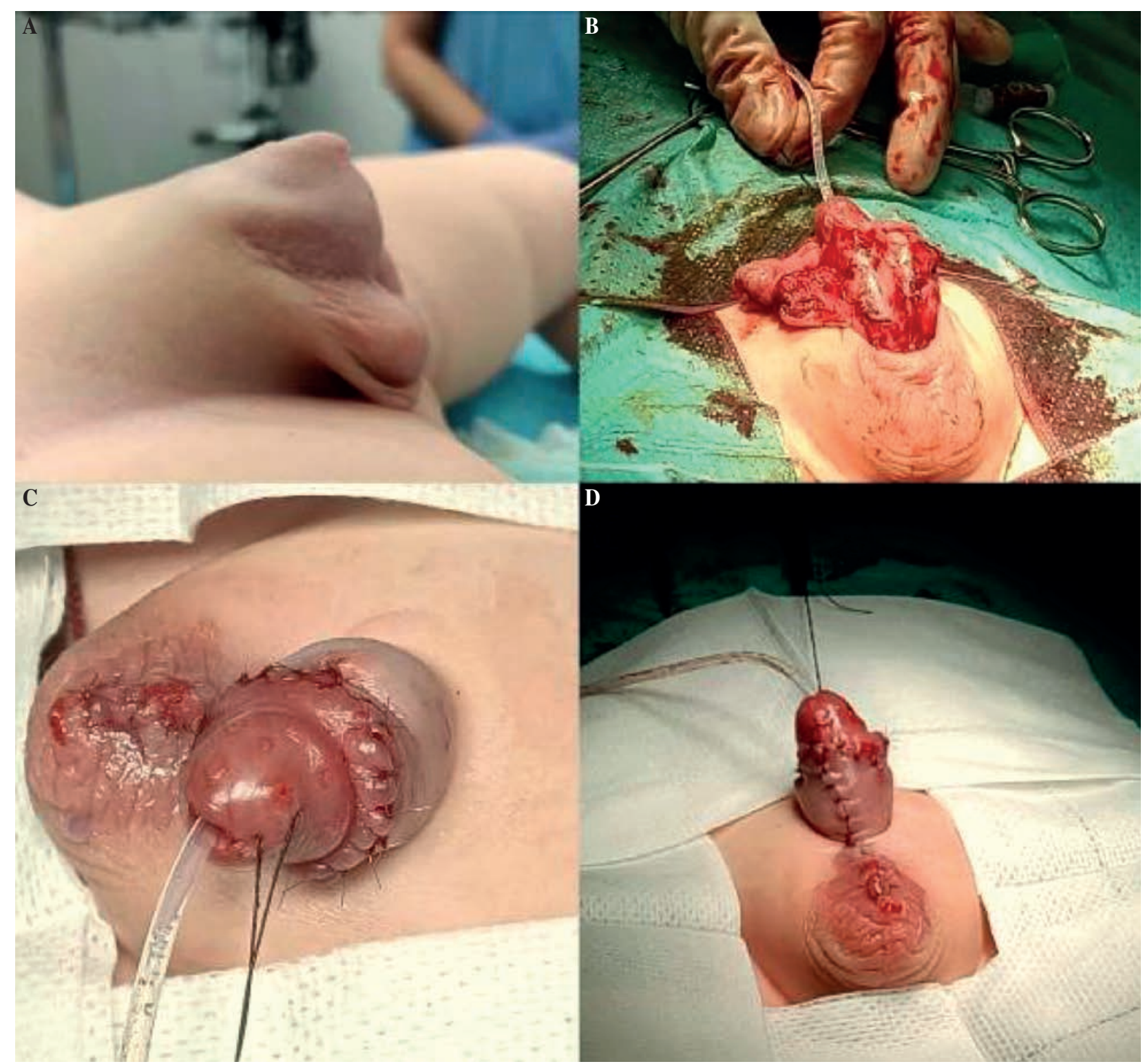

Figure 3. Clinical case 3. A) Baseline status, with evident ballooning. B) Surgical repair according to the "anatomical approach" technique. C) Ulcerative lesions found on the glans following glans exposure during surgery. D) Immediate postoperative result.

of the penis differed - the second and third patients had a more satisfactory early esthetic progression than the patient undergoing regulated circumcision (Fig. 4).

\section{DISCUSSION}

Congenital megaprepuce is a rare pathology, and it can be mistaken for other pathologies such as physiological phimosis or buried penis. Given that clinical presentation is usually symptomatic (with preputial ballooning), and association with urinary tract infections or local cutaneous involvement as a result of chemical irritation is not infrequent, early surgical management is indicated - as opposed to phimosis patients in this age group, where it is regarded as physiological. Since this pathology has its own therapeutic and surgical implications, we believe it should be considered when performing the differential diagnosis of penile disorders in early childhood. Multiple techniques for surgical repair have been described - ventral V-plasty, genitoplasty with penoscrotal separation, double longitudinal megrapreputium incision technique (DOLOMITE), arch incision approach, and anatomical reconstruction ${ }^{(3-6)}$.

Today, there is little information regarding the midand long-term follow-up of these patients in the literature, which means further studies are required. 

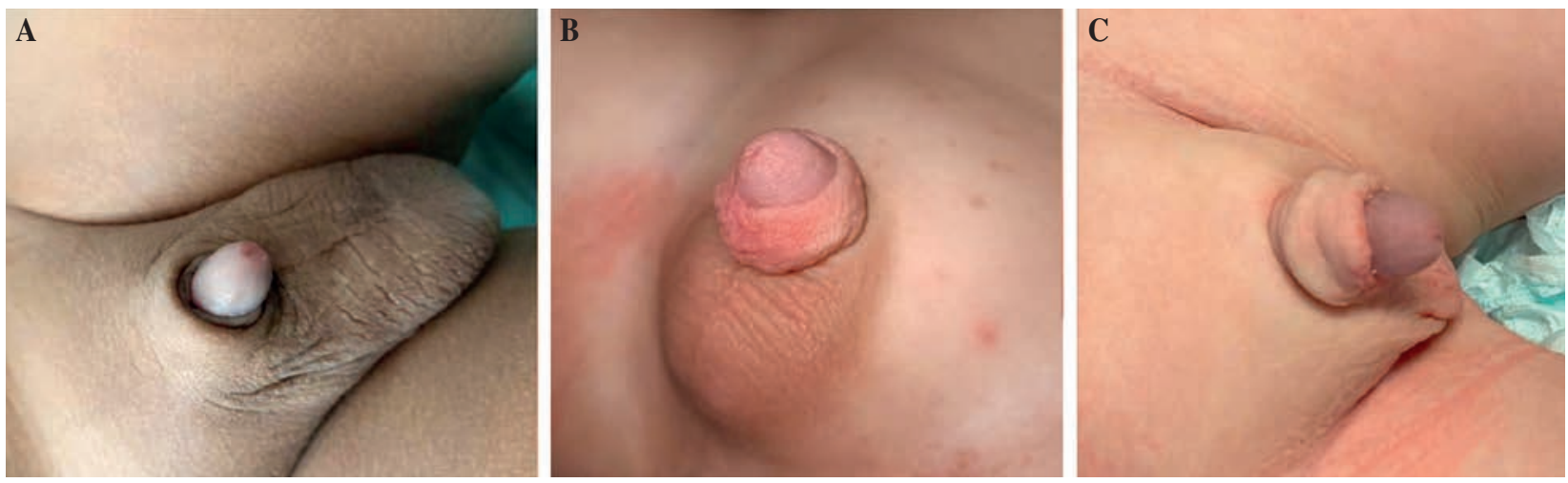

Figure 4. Postoperative progression six months following surgery. A) Patient 1. B) Patient 2. C) Patient 3.

\section{REFERENCES}

1. Werner Z, Hajiran A, Al-Omar O. Congenital Megaprepuce: Literature Review and Surgical Correction. Case Rep Urol. 2019; 2019: 1-6.

2. Delgado Oliva FJ, Domínguez Hinarejos C, Serrano Durbá S, Estornell Moragues F, Martínez Verduch M, García Ibarra F. Megaprepucio congénito: diagnóstico y manejo terapéutico. Actas Urol Esp [Internet]. 2006 [citado 2019 Dic 25]; 30(10): 1038-42.

3. Alexander A, Lorenzo AJ, Salle JLP, Rode H. The Ventral V-plasty: A simple procedure for the reconstruction of a congenital megaprepuce. J Pediatr Surg [Internet]. 2010; 45(8): 1741-7.
4. Callewaert PRH, Rahnama'I MS, Guimarães MNC, Vrijens DMJ, Van Kerrebroeck PEVA. DOuble LOngitudinal megapreputium incision TEchnique: The Dolomite. Urology [Internet]. 2014; 83(5): 1149-54.

5. Lin HW, Zhang L, Geng HQ, Fang XL, Xu GF, Xu MS, et al. An arc incision surgical approach in congenital megaprepuce. Chin Med J (Engl). 2015; 128(4): 555.

6. Lasso Betancor CE, Cherian A, Smeulders N, Mushtaq I, Cuckow P. Mid- to long-term outcomes of the 'anatomical approach' to congenital megaprepuce repair. J Pediatr Urol. 2019; 15(3): 243.e1-243.e6. 